\title{
THE IMPACT OF ETHICAL PERCEPTIONS OF SMALL AND MEDIUM SIZED ENTERPRISES (SMEs) ON THEIR BANK SATISFACTION AND SUBSEQUENT WORD OF MOUTH: CASE OF NORTHERN CYPRUS
}

Doç. Dr. Okan Veli ŞAFAKLI, Yakın Doğu University, Faculty of Economics and Administrative Sciences, Department of Banking and Finance, safakli@neu.edu.tr

\begin{abstract}
Competitive advantage and longstanding survival of the banking sector do not depend only on market oriented service production but also on wining public confidence. The crucial condition of wining public confidence is to comply with ethical standards. In this respect, the main aim of this study is to determine the perceived ethical quality of commercial banks from the viewpoint of SMEs in Northern Cyprus. As a summary of the research 21 ethical principles used in the research have been grouped into three factors for which perceived ethical behaviors are not satisfactory. Furthermore, regression analysis reveals that three ethical factors named as "procedural justice", "assurance" and sensitivity" have an explanatory effect on their bank satisfaction while SMEs' bank satisfaction have an explanatory effect on their word of mouth.
\end{abstract}

Keyword: Northern Cyprus, Ethical Quality, SMEs, Bank Satisfaction, Word of Mouth

\section{INTRODUCTION}

Historical lessons taken as a result of banking crisis reveal that public confidence is the key to the success and survival of commercial banks. Uncertainty about the health of the banking system in general can lead to runs on banks both good and bad, and the failure of one bank can hasten the failure of others (referred to as the contagion effect). If nothing is done to restore the public's confidence, a bank panic can ensue (Mishkin, 2007, p. 280). Therefore, regulatory authorities take necessary measures to restore and preserve public confidence. However, commercial banks should also put their best foot forward to gain public confidence and hence reputation. Unsurprisingly, perceived ethics of a company affect its reputation. Good reputations ensure long term success. 
With them you get better people, better sales and a better bottom line. Realizing that good strategy and prudent management is sine qua non for business success no businesses will survive for very long on a record of acting unethically (Green, 1989, p. 631). In other words, banking is fundamentally a business of trust. If we don't have our customers' trust, we won't have their business (Fergeson, 2004, p.14). In this respect, the aim of this study is to investigate ethical perceptions of Small and Medium Sized Enterprises (SMEs) towards commercial banks in Northern Cyprus and to make recommendations accordingly so as to increase the ethical conformance of the banks. Furthermore, the relationships "between ethical perceptions of SMEs and their bank satisfaction" and "between their bank satisfaction and worth of mouth" are also examined. Being the backbone of the economy perceptions of SMEs in Northern Cyprus can be assessed as the forthcoming indicator of banks' ethical quality. According to the '1998 Census of General Industry and Workplace' which was made firstly by T.R.N.C Prime Ministry State Planning Organization's Statistics and Research Department, SMEs constitute approximately 99,8 percent of the number of the total enterprises. The share of these SMEs in the total employment is approximately 80 percent (Songür, 2002, p.1).

\section{LITERATURE REVIEW}

Ethical quality of commercial banks is directly related to the compliance with the standards of good banking practices formulized as "code of banking ethics". These standards are necessary to ensure that the existing respect for the banking profession in the society is set on a permanent footing, to maintain and improve this social respect, called also as professional honor, and to maintain and protect the stability and trust in the banking sector (TBB 2006, p. 1; Stein and Yassa 2005). Since being perceived as trustworthy is crucial for the survival of a bank (Chiami and Fullenkamp, 2002), a respectable bank, being an intermediary between the depositor and creditor is expected to have honesty, integrity (Provis, 2001; Lynch, 1991, p.3), social responsibility, accountability and fairness not to damage reputation and prevent financial loss (Carse, 1999; Souter et al., 1994; Brickley et al, 2002, pp.1821-1835). Therefore, commercial banks must act in a manner that merits public trust, confidence and reputation by integrating core values - such as honesty, trust, respect, and fairness -- into its policies, practices, and decision making and apprehending compliance with legal standards and adherence to internal rules and regulations. Although it is almost impossible to come across with any respectable bank that would claim not to attach high importance to core ethical values, to accept bribes in return for loans, to lend to connected parties and to cheat customers, it is observed that there is sometimes a gap between what banks claim and what they do. History demonstrated that bribery and corruption have been one of the root causes of the banking problems (Carse, 1999). Some of the common non-ethical behaviours in the banking sector can be revealed as bribery, misuse of authority, and exploitation (Hauri 2000; Carse 1999), connected lending (Eichengreen \& Rose 1988, p.2; Hoening, 1999;Goldstein \& Turner 1996, p.21), lack of transparency (Coşkun 2001, p.4) and the political 
interferences (Parasız 2000, p.227; Öçal \& Çolak 1999, pp. 284-285). When the banking crises starting at the beginning of 2000 in Northern Cyprus is analyzed, it is found out that unethical behaviours such as working against regulations, political interference, asymmetric information, fraud of bank owners and connected lending were among the main causes (Şafaklı 2005, pp. 28-29; Şafaklı 2003).

In their study Hortacsu and Gunay (2004) specified non-ethical behaviors as fraud and forgery, bribery, customer discrimination, power pressure, lying and cheating, robbery by workers, insider trading, spreading negative information and refraining from undesirable information, industry espionage, harming the environment, interest conflict, breaching personal secrecy and money laundering .

Schwartz, (2002) pointed out the set of universal moral standards including (1) trustworthiness; (2) respect; (3) responsibility; (4) fairness; (5) caring; and (6) citizenship.

Cowton (2002) emphasized the importance of three aspects of ethics in banking as integrity, responsibility and affinity.

Banyard (2006) considers the issue of transparency in today's global banking industry.

Cowton and Thomson (2000) stated the ethical behavior of improving the quality of natural environment.

Waddock (2006) examined the related efforts to create more corporate responsibility, accountability, and transparency.

Tsahuridu and Perryer (2002) studied the linkage between ethics and integrity.

In the banking sector of many countries, the main ethical principles such as honesty, impartiality, trustworthiness, harmonization with the legislation of the bank and transparency, integrity, responsibility, accountability, social responsibility and justice have been introduced in written form and taken into consideration (Şafaklı 2006, p.113). Basic code of banking ethics applied practically consists of transparency of transactions, confidentiality and banking secrecy, collecting and keeping information on customers, proper use and care of information and proper record keeping, giving right to suspicion, promotion of banking services, service to customers, handling customers complaints, compliance with the Code, honesty, impartiality, reliability, observing social benefit and respect to environment, fighting with laundering of crime-originated assets, insider trading, avoiding conflicts of interest, refraining from bribery and corruption, self development and development of others, positive and fair dealings with officials, government representatives and competitors (Hellenic 
Bank Association 1997; TBB 2006; Alliance Bank 2006; Central Bank of Kenya, 2006; International Moscow Bank 2006; The First national Bank in Trinidad 2006; The Bank of New York 2006).

\section{METHODOLOGY}

As pointed out above the main aim of the research is to investigate ethical perceptions of Small and Medium Sized Enterprises (SMEs) towards commercial banks in Northern Cyprus and to determine the impact of these perceptions on their bank satisfaction in order to make recommendations accordingly so as to increase the ethical conformance of the banks. The research applying non-probability convenience sampling (Sekaran, 2003, p. 276) towards the owners/managers of SMES operating in versatile sectors at the township of Nicosia was conducted during the period of May 2007, completing 239 valid questionnaires from 500 questionnaires distributed to SMEs that approximately constitute $4 \%$ of SMEs in Northern Cyprus. The questionnaire used in the study is comprised of four parts. Part A contains demographic profile of respondents including gender, age group, marital status, education, relevant sector, type of commercial bank they usually work with. Part $B$ includes perceptions of respondents using a seven-point Likert scale ranging from "strongly disagree $=1$ " to "strongly agree $=7$ " so as to measure the satisfactory level for 21 ethical behavior as the code of ethics. According to literature review of theoretical and practical issues the 21 ethical behaviors are determined as considering public benefit, refraining from misinformation, honesty, refraining from bribery, secrecy, social responsibility, accuracy, objectivity, .confidentiality, respecting customers, not to lie, transparency, good sense, independency, open minded, consistency, quality of services, harmonization with legislation, impartiality, escaping from unfair competition and finalization of customers' complaints. In part C and D respondents are required to express their "degree of overall satisfaction with the bank" and "degree of recommendation of the bank to others" respectively by using fivepoint Likert scale ranging from " $1=$ very bad" to " $5=$ very good". The data was analyzed with the Statistical Package Program for Social Sciences (SPSS 12 for Windows). Both demographic and ethical items were tested to check if they were parametric or not. According to "One-Sample Kolmogorov-Smirnov Test" all variables proved to be normally distributed. Therefore, parametric tests have been applied in the study. Respondents' ratings on the satisfactory level of ethical variables were subjected to principal factor analysis to identify a small number of factors that may be used to represent relationship among sets of

\footnotetext{
* In non-probability sampling designs, the elements in the population do not have any probabilities attached to their being chosen as sample subjects. This means that the findings from the study of the sample can not be confidently generalized to the population. As it name implies, convenience sampling refers to the collection of information from members of the population who are conveniently available to provide it.
} 
THE IMPACT OF ETHICAL PERCEPTIONS OF SMALL AND MEDIUM SIZED

ENTERPRISES (SMES) ON THEIR BANK SATISFACTION

AND SUBSEQUENT WORD OF MOUTH: CASE OF NORTHERN CYPRUS

interrelated variables. The hypotheses to be tested in the study are given as follows:

H1. Perceived ethical variables for commercial banks are not satisfactory

H2. Perceived ethical factors for commercial banks are not satisfactory

H3. There is no any correlation between ethical factors

H4. There are no significant differences between the assessments according to SMEs' demographic factors and perceived ethical factors.

H5. There is no positive significant impact of perceived ethical factors on SMEs' bank satisfaction

H6. There is no positive significant impact of SMEs' bank satisfaction on their word of mouth about the banks.

The basic analysis and tests utilized in the study include frequency and percentage analysis, "one-sample $t$ test", "independent-samples $t$ tests", "paired-samples $t$ tests", "One-Way ANOVA test", "reliability analysis", "factor analysis" and "regression analysis"

\section{DISCUSSION OF FINDINGS AND HYPOTHESES TESTING}

The basic findings related to demographic characteristics of owners/managers of SMEs examined in the survey are given in Table 1.

As can be seen in the table, sample of SMEs assessing the ethical behavior of commercial banks included more males (69 percent) than females, more high school education (46.9 percent) than other categories, and more married (74.9 percent) than other categories. Majority of them was 45 and below (72.9 percent), operates in the sectors of" business and personal services" and "tradetourism" (82.1 percent), and usually works with local banks (76.2 percent).

\section{Testing $\mathrm{H1}$}

The results of "one-sample $t$ test" reflecting the average perceived ethical behaviors of commercial banks are shown in Table 2 . 
Table 1: Demographic Findings

\begin{tabular}{|l|l|c|}
\hline Factor & Category & Percentage \\
\hline Gender & Male & 69 \\
\cline { 2 - 3 } & Female & 31 \\
\hline \multirow{4}{*}{ Age group } & 25 and below & 5.9 \\
\cline { 2 - 3 } & $26-35$ & 28.9 \\
\cline { 2 - 3 } & $36-45$ & 38.1 \\
\cline { 2 - 3 } & 46 and above & 27.2 \\
\hline \multirow{4}{*}{ Earital status } & Single & 22.2 \\
\cline { 2 - 3 } & Married & 74.9 \\
\cline { 2 - 3 } & Widow & 2.9 \\
\hline \multirow{4}{*}{ Sectucation } & Primary school & 5.9 \\
\cline { 2 - 3 } & Secondary school & 7.1 \\
\cline { 2 - 3 } & High school & 46.9 \\
\cline { 2 - 3 } & University and Master degree & 39.7 \\
\cline { 2 - 3 } & Doctorate & 0.4 \\
\hline \multirow{4}{*}{ sMEs take place } & Agriculture & 1.7 \\
\cline { 2 - 3 } & Industry & 5.9 \\
\cline { 2 - 3 } & Construction & 7.5 \\
\cline { 2 - 3 } & Trade-Tourism & 33.1 \\
\cline { 2 - 3 } & Transport-Communication & 1.7 \\
\cline { 2 - 3 } & Financial institutions & 1.3 \\
\cline { 2 - 3 } & Business and Personal Services & 49 \\
\hline & Turkish branch banks & 18.4 \\
\cline { 2 - 3 } & Local banks & 76.2 \\
\cline { 2 - 3 } & HSBC & 5.4 \\
\hline \multirow{2}{*}{$\begin{array}{l}\text { Commercial } \\
\text { SMith usually wank }\end{array}$} & \\
\hline
\end{tabular}

According to "One-Sample t-test", the means of perceptions have been tested if they differ significantly from 4 which are tantamount to "undecided" as shown in Table 2. This one-sample $t$ test analysis indicates that means of 19 out of 21 ethical principles are significantly lower at the $p<0.05$ level than 4 while the means of remaining 2 ethical behaviors which are objectivity and respecting customers do not significantly differ from 4 at the same level. In other words, perceived ethical behaviors of commercial banks are either unsatisfactory or undecided position. Therefore, $\mathrm{H} 1$ can be accepted. After the "one-sample $t$ test" for ethical behaviors, a factor analysis was conducted using varimax rotation (see Table 3). 
THE IMPACT OF ETHICAL PERCEPTIONS OF SMALL AND MEDIUM SIZED ENTERPRISES (SMES) ON THEIR BANK SATISFACTION AND SUBSEQUENT WORD OF MOUTH: CASE OF NORTHERN CYPRUS

Table 2: One-Sample Statistics and Test for Perceived Ethical Behaviors of Commercial Banks in Northern Cyprus

\begin{tabular}{|c|c|c|c|}
\hline Variables & Mean & Std. Deviation & $\begin{array}{c}\text { Sig. (2-tailed) } \\
\text { Test Value }=4 \\
(p)\end{array}$ \\
\hline $\begin{array}{l}\text { 1.Considering Public } \\
\text { Benefit }\end{array}$ & 3,22 & 1,69 & ,000 \\
\hline $\begin{array}{l}\text { 2.Refraining from } \\
\text { misinformation }\end{array}$ & 3,58 & 1,39 &, 000 \\
\hline 3. Honesty & 3,63 & 1,34 &, 000 \\
\hline 4.Refraining from bribery & 3,50 & 2,31 & ,001 \\
\hline 5.Secrecy & 3,33 & 1,56 & ,000 \\
\hline 6.Social Responsibility & 3,60 & 1,45 &, 000 \\
\hline 7.Accuracy & 3,46 & 1,45 & ,000 \\
\hline 8.Objectivity & 3,63 & 4,14 & ,171 \\
\hline 9.Confidentiality & 3,57 & 1,47 & ,000 \\
\hline $\begin{array}{l}\text { 10.Respecting } \\
\text { Customers }\end{array}$ & 3,83 & 1,32 & ,058 \\
\hline 11.Not to lie & 3,43 & 1,47 &, 000 \\
\hline 12.Transparency & 3,21 & 1,59 & ,000 \\
\hline 13.Good Sense & 3,25 & 1,49 & ,000 \\
\hline 14.Independency & 3,09 & 1,62 &, 000 \\
\hline 15.Open minded & 3,30 & 1,54 &, 000 \\
\hline 16.Consistency & 3,40 & 1,47 &, 000 \\
\hline 17.Quality of services & 3,45 & 1,63 &, 000 \\
\hline $\begin{array}{l}\text { 18. Harmonization with } \\
\text { legislation }\end{array}$ & 3,48 & 1,48 &, 000 \\
\hline 19.Impartiality & 2,51 & 2,07 &, 000 \\
\hline $\begin{array}{l}\text { 20.Escaping from unfair } \\
\text { competition }\end{array}$ & 3,10 & 1,65 &, 000 \\
\hline $\begin{array}{l}\text { 21.Finalization of } \\
\text { customers' complaints }\end{array}$ & 3,29 & 1,91 & ,000 \\
\hline
\end{tabular}

Values of Scale: 1 = strongly disagree, $2=$ disagree, $3=$ partly disagree $4=$ Undecided, $5=$ partly agree, $6=$ agree and $7=$ strongly agree

Regarding the pre-analysis testing for the suitability of the entire sample for factor analysis, the Kaiser-Meyer-Olkin measure of sampling adequacy was 0.916 and the Bartlet tests of sphericity (2198.628) was significant at $p<0.01$, thus, indicating that sample was suitable for factor analytic procedures. According to analysis, factors with eigenvalues greater than 1.0 and factor loadings that are equal to or greater than 0.50 were retained. 17 items, loading 
under three dimensions were extracted from the analysis except four items that are objectivity, refraining from bribery, impartiality and respecting customers and these 17 items explained 60.848 percent of the overall variance. As it is understood, along with the pre-reliability and factor analysis, the variables whose averages do not significantly differ from 4 are taken out of the consideration. Therefore, all the variables left show unsatisfactory perceived ethical behavior supporting the acceptance of $H 1$.

Table 3: Results of Factor Analysis on 17 Variables and its three dimensions

\begin{tabular}{|c|c|c|c|c|}
\hline Factors and Variables & Eigenvalue & $\begin{array}{l}\text { Factor } \\
\text { loadings }\end{array}$ & $\begin{array}{l}\text { Variance } \\
\text { (\%) }\end{array}$ & $\begin{array}{l}\text { Cronbach } \\
\text { alpha }\end{array}$ \\
\hline Factor 1 & 8.172 & & 22.847 & .860 \\
\hline Independency & & 827 & & \\
\hline Open minded & & ,692 & & \\
\hline Social Responsibility & & ,618 & & \\
\hline $\begin{array}{l}\text { Escaping from unfair } \\
\text { competition }\end{array}$ & & ,600 & & \\
\hline Secrecy & & ,569 & & \\
\hline Consistency & & 551 & & \\
\hline Considering Public Benefit & &, 524 & & \\
\hline Factor 2 & 1.555 & & 20.886 & .875 \\
\hline $\begin{array}{l}\text { Refraining from } \\
\text { misinformation }\end{array}$ & & 829 & & \\
\hline Honesty & & 745 & & \\
\hline Confidentiality & & ,642 & & \\
\hline Accuracy & & ,578 & & \\
\hline $\begin{array}{l}\text { Harmonization with } \\
\text { legislation }\end{array}$ & & ,574 & & \\
\hline Not to lie & & ,560 & & \\
\hline Factor 3 & 1.018 & & 17.116 & .793 \\
\hline $\begin{array}{l}\text { Finalization of customers' } \\
\text { complaints }\end{array}$ & & 850 & & \\
\hline Quality of services & & 708 & & \\
\hline Transparency & & 655 & & \\
\hline Good Sense & & ,553 & & \\
\hline
\end{tabular}


Overall alpha coefficient as the reliability analysis is 0.930 . Items for each subscale were also subjected to reliability analysis. The alpha coefficients for the total scale were $0.860,0.875$ and 0.793 respectively for the three dimensions. Reliability coefficient above 0.7 is considered sufficient (George and Mallery 2001, p. 217).

\section{Testing $\mathrm{H} 2$}

The three factors determined according to factor analysis are named as "procedural justice", "assurance" and "sensitivity". These factors shown in Table 4 were subjected to "one-sample $t$ test". Average values of perceived ethical behaviors for these three factors are significantly lower than 4 at $p<0.01$. This leads to the acceptance of $\mathrm{H} 2$ stating that perceived ethical factors for commercial banks are not satisfactory

Table 4: One-Sample Statistics and Test for Ethical Factors

\begin{tabular}{|l|c|c|c|}
\hline Factors & Mean & \multicolumn{1}{|c|}{$\begin{array}{c}\text { Std. } \\
\text { Deviation }\end{array}$} & $\begin{array}{c}\text { Sig. (2-tailed) } \\
\text { Test Value =4 } \\
(\boldsymbol{p})\end{array}$ \\
\hline $\begin{array}{l}\text { Procedural Justice } \\
\text { (Factor1) }\end{array}$ & 3,2977 & 1,16125 & .000 \\
\hline Assurance (Factor2) & 3,5300 & 1,12901 & .000 \\
\hline Sensitivity (Factor3) & 3,3044 & 1,30777 & .000 \\
\hline
\end{tabular}

\section{Testing $\mathrm{H3}$}

As Table 5 indicates, among all the factors positive correlations (at $p<0.01)$ exist. In other words, when the average value of perceived ethicality for any factor increases the average values of perceived ethicality for other factors also tend to rise. Strong positive correlation exists between procedural justice and sensitivity while the degree of other correlations can be evaluated as weak. This necessitates the rejection of $H 3$ which asserts that there are no correlations between ethical factors

Table 5: Correlation (Pearson Correlation ) Matrix for Ethical Factors

\begin{tabular}{|l|c|c|c|}
\hline & $\begin{array}{c}\text { Procedural } \\
\text { Justice }\end{array}$ & Assurance & Sensitivity \\
\hline $\begin{array}{l}\text { Procedural } \\
\text { Justice }\end{array}$ & 1 & & \\
\hline Assurance &, $773\left(^{* \star}\right)$ & 1 & \\
\hline Sensitivity &, $678\left(^{* *}\right)$ &, $657\left(^{* *}\right)$ & 1 \\
\hline
\end{tabular}

${ }^{* *}$ Correlation is significant at the 0.01 level (2-tailed). 


\section{Testing $\mathrm{H4}$}

Table 6: The Impact of Demographic Variables on the Perceived Ethical Factors Using Analysis of Variance

\begin{tabular}{|c|c|c|c|}
\hline & $\begin{array}{l}\text { Procedural } \\
\text { Justice }\end{array}$ & Assurance & Sensitivity \\
\hline \multicolumn{4}{|l|}{ Sex } \\
\hline Female & 3,380 & 3,464 & 3,510 \\
\hline Male & 3,260 & 3,559 & 3,212 \\
\hline$(F)$ & 3,214 & 1,913 & 6,953 \\
\hline \multicolumn{4}{|l|}{ Age group } \\
\hline 25 and below & 3,265 & 3,297 & 3,339 \\
\hline $26-35$ & 3,180 & 3,393 & 3,047 \\
\hline $36-45$ & 3,299 & 3,582 & 3,343 \\
\hline 46 and above & 3,426 & 3,651 & 3,515 \\
\hline$(\mathrm{F})$ &, 502 &, 847 & 1,494 \\
\hline \multicolumn{4}{|l|}{ Marital status } \\
\hline Single & 3,000 & 3,295 & 2,943 \\
\hline Married & 3,391 & 3,595 & 3,403 \\
\hline Widow & 3,163 & 3,619 & 3,500 \\
\hline$(F)$ & 2,395 & 1,475 & 2,649 \\
\hline \multicolumn{4}{|l|}{ Education } \\
\hline Primary school & 3,795 & 4,107 & 3,678 \\
\hline Secondary school & 2,453 & 2,794 & 2,647 \\
\hline High school & 3,434 & 3,601 & 3,457 \\
\hline University and Master degree & 3,215 & 3,498 & 3,189 \\
\hline Doctorate & 3,142 & 3,000 & 3,000 \\
\hline$(\mathrm{F})$ & $3,551^{* *}$ & $3,003^{*}$ & 1,973 \\
\hline \multicolumn{4}{|l|}{ Sector in which SMEs take place } \\
\hline Agriculture & 2,178 & 2,291 & 2,062 \\
\hline Industry & 3,142 & 3,131 & 3,535 \\
\hline Construction & 3,325 & 3,787 & 3,652 \\
\hline Trade-Tourism & 3,493 & 3,679 & 3,265 \\
\hline Transport-Communication & 2,964 & 2,958 & 3,312 \\
\hline Financial institutions & 3,571 & 3,611 & 3,250 \\
\hline Business and Personal Services & 3,222 & 3,497 & 3,292 \\
\hline$(\mathrm{F})$ & 1,209 & 1,699 &, 899 \\
\hline \multicolumn{4}{|l|}{$\begin{array}{l}\text { Commercial Bank SMEs usually } \\
\text { work with }\end{array}$} \\
\hline Turkish branch banks & 2,974 & 3,352 & 2,892 \\
\hline Local banks & 3,372 & 3,609 & 3,384 \\
\hline HSBC & 3,351 & 3,025 & 3,576 \\
\hline$(\mathrm{F})$ & 2,116 & 2,313 & 2,856 \\
\hline \multicolumn{4}{|c|}{$\begin{array}{l}{ }^{* *} p<0.01 \\
{ }^{*} p<0.05 \\
\text { Note: Means are represented in terms of average perceived ethical factors }\end{array}$} \\
\hline
\end{tabular}


Referring to demographic characteristics of owners/managers of SMEs in Northern Cyprus at Table 1 "Independent-Samples $t$ test" and "One-Way ANOVA test" were used to determine if the means of perceived ethical factors varied among different demographic characteristics. Findings indicated that only one of the characteristics, education yielded significant differences at the 0.01 level for procedural justice and 0.05 levels for assurance in disparity of perceived ethical factors as shown in Table 6 . Both of the perceived ethical factors show similar pattern of behavior. Such that lowest averages of perceived ethical factors belong to owners/managers of SMEs with secondary school education while highest averages of perceived ethical factors belong to owners/managers of SMEs with primary school education. Eventually, $\mathrm{H} 4$ is rejected for only education as the demographic factor.

\section{Testing $\mathrm{H} 5$ and $\mathrm{H} 6$}

The relative importance of the three ethical factors in the prediction of overal SMEs' satisfaction and the strenght of this satisfaction on positive word of mouth constitiute two models ilustrated in Figure 1.

Figure 1: Impact of Ethical Factors on Overall Customer Satisfaction and Recommendation of Bank to Others

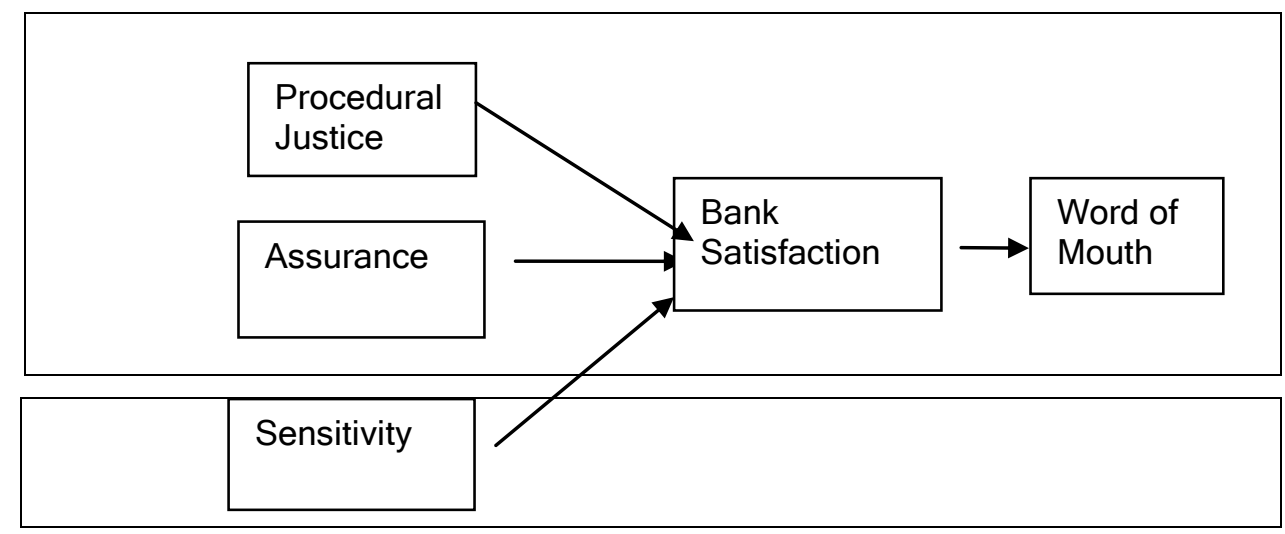

According to this models, ethical factors are assumed to impact bank satisfaction ( $\mathrm{H} 5)$ while the satisfied customer is expected to engage in positive word of mouth about the bank (H6) (Zeithaml et al., 1996). The relationships hypothesized in Figure 1 was tested by using multiple regression analysis. 
The regression models will have the following forms

\section{Model 1 Assurance, sensitivity)}

Overall Bank Satisfaction $=f($ procedural justice,

The summary of the multiple regression results of Model 1 are shown in Table 7. As seen in Table $7 R$-square is 0.466 indicating that variations in perceived ethical factors explain 46.6 percent of the variation in bank satisfaction. This $R$ square is significant at the 0.001 level. However, the coefficient of only sensitivity is found to be significant at the 0.01 level. The direction of influence for this ethical factor is positive being suitable for the theory. The $\beta$ value of .525 indicates that 1 unit change in sensitivity will lead to .525 changes in bank satisfaction. The other two ethical factors do not have significant impact on bank satisfaction.

Table 7: Summary of the Regression Results of Model 1

\begin{tabular}{|c|c|c|c|c|c|c|}
\hline Model 1 & Predictors & Beta & $t$ & $\begin{array}{l}\text { Sig. } \\
\text { level }\end{array}$ & $\begin{array}{l}\text { Conditio } \\
\text { n Index }\end{array}$ & $\begin{array}{l}\text { Toleranc } \\
\text { e value }\end{array}$ \\
\hline \multirow{4}{*}{$\begin{array}{l}\text { a. Dependent } \\
\text { Variable: Bank } \\
\text { Satisfaction } \\
\text { b. Predictors: } \\
\text { Procedural } \\
\text { Justice, } \\
\text { Assurance, } \\
\text { Sensitivity }\end{array}$} & (Constant) & 2,090 & 14,860 & ,000 & 1,000 & \\
\hline & $\begin{array}{l}\text { Procedural } \\
\text { Justice }\end{array}$ & 114 & 1,413 & 159 & 7,271 & .352 \\
\hline & Assurance & ,099 & 1,267 & 206 & 9,471 & .371 \\
\hline & Sensitivity & ,525 & 7,760 & ,000 & 13,069 & .496 \\
\hline & 50 & 1ev & 0.000 & & & \\
\hline
\end{tabular}

The summary of the simple regression results of Model 2 are shown in Table 8. As seen in Table $8 R$-square is 0.659 indicating that bank satisfaction explains 65.9 percent of the variation in the recommendation of the bank to others. This $R$-square is significant at the 0.001 level. The coefficient of bank satisfaction expectedly is found to be significant at the 0.01 level. The direction of influence is positive being suitable for the theory. The $\beta$ value of .812 indicates that 1 unit change in bank satisfaction will lead to .812 changes in the word of mouth. 
THE IMPACT OF ETHICAL PERCEPTIONS OF SMALL AND MEDIUM SIZED ENTERPRISES (SMES) ON THEIR BANK SATISFACTION AND SUBSEQUENT WORD OF MOUTH: CASE OF NORTHERN CYPRUS

Table 8: Summary of the Regression Results of Model 2

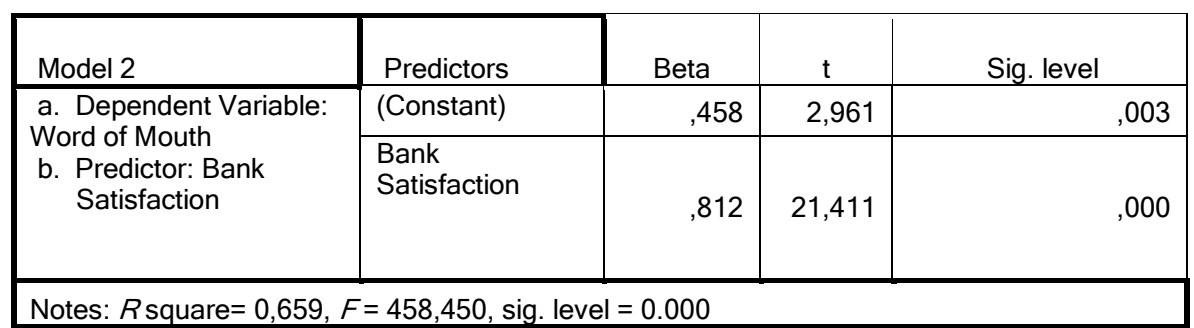

The multiple regression model established above should also be tested in relation to crucial problem of 'multicollinearity'. Tolerance values and condition index are the important indicators of multicollinearity. As shown in Table 7 tolerance values which are not all that close to zero and the values in the condition index not being over 15 show that there is no indication of a major problem with collinearity ( Ross, 2004).

In the light of the above results related to Model 1 and Model 2, $\mathrm{H} 5$ and $\mathrm{H} 6$ can be rejected. Therefore, we can conclude that ethical factors have an explanatory effect on bank satisfaction while bank satisfaction has an explanatory effect on the word of mouth.

\section{CONCLUSION AND MANAGERIAL IMPLICATIONS}

Historical lessons show that sustainability of organizational success especially for banking sector mainly depends on public confidence. Indispensable part of public confidence relies on ethical conformance. Therefore, ethical conformance is expected to influence bank customer satisfaction. In this study, ethical perceptions of SMEs as the backbone of the Northern Cyprus' economy towards the commercial banks are examined so as to determine their impact on bank satisfaction.

Research findings reveal that perceived ethical behaviors of commercial banks towards SMEs in Northern Cyprus are unsatisfactory. SMEs are not satisfied with the performance of commercial banks, covering the all types of ethical variables.

According to factor analysis ethical variables have been grouped into three crucial ethical factors named as "procedural justice", "assurance" and "sensitivity". In terms of these factors, SMEs appraise commercial banks as not performing satisfactory ethical behaviors. 
Considering the demographic characteristics of owners/managers of SMEs, perceived ethical behaviors of commercial banks differentiated in terms of only education towards procedural justice and assurance.

Among the ethical factors, only sensitivity is statistically confirmed to have explanatory effect on bank satisfaction.

Research findings support the theoretical foresight that bank satisfaction will lead to the recommendation of banks to others.

In the light of conclusive remarks, notable managerial implications that ought to be taken into account by commercial banks should be referred. Commercial banks should pay enough attention to meet the ethical expectations of SMEs in order to smooth the progress of gaining and preserving public confidence. In this regard, procedural justice, assurance and sensitivity are the vital ethical issues to be focused by commercial banks. Among these ethical issues primary attention should be given to sensitivity since it is the single one significantly influencing bank satisfaction. Furthermore, commercial banks should keep in their mind that the degree of satisfying ethical expectations differentiates according to educational level of managers/owners of SMEs

\section{REFERENCES}

ALLIANCE BANK (2006), Code of Ethics, Retrieved August 25, 2006 from the World Wide Web: http://www.alliancebankva.com/page.cfm?pagelD=12

BANYARD, P. (2006), "Some Surprises Along the Way", Credit Management, June 2006: 22.

BRICKLEY, J.A., SMITH, C.W., ZIMMERMAN, J.L. (2002), "Business Ethics and Organizational Architecture", Journal of Banking and Finance, 26 (9).

CARSE, D. (1999), "The Importance of Ethics in Banking," Speech in Banking Conference on Business Ethics, Hong Kong, September 15, 1999.

CENTRAL BANK OF KENYA (2006), Code of Conduct, Retrieved August 25, 2006 from the World Wide Web: http://www.centralbank.go.ke/about/codeofconduct.html\#bribery

CHAMI, R. AND C. FULLENKAMP. (2002), "Trust and Efficiency," Journal of Banking and Finance, 26, 1785-1809.

COŞKUN, N. (2001), "The Swiss Financial Centre: Achievements and Challenges", Speech on Financial Excellence, Milan.

COWTON, C.J. (2002), "Integrity, Responsibility and Affinity: Three Aspects of Ethics in Banking", Business Ethics: A European Review, 11(4): 393-400. 
THE IMPACT OF ETHICAL PERCEPTIONS OF SMALL AND MEDIUM SIZED ENTERPRISES (SMES) ON THEIR BANK SATISFACTION AND SUBSEQUENT WORD OF MOUTH: CASE OF NORTHERN CYPRUS

COWTON, C.J. AND THOMPSON, P. (2000), "Do Codes Make a Difference? The Case of Bank Lending and the Environment", Journal of Business Ethics, 24(2): 165-178.

GEORGE, D. AND MALLERY, P. (2001), SPSS for Windows, Third Edition, Allyn \& Bacon/Pearson Education Company.

GOLDSTEIN, M AND TURNER, P. (1996), "Banking Crises in Emerging Economics: Origins and Policy Options”, BIS Economic Papers, No:46, October.

GREEN, C. F. (1989), "Business Ethics in Banking", Journal of Business Ethics, 8(8): 631-634.

EICHENGREEN, B. AND ROSE, A. K. (1998), "Staying Afloat When the Wind Shifts: External Factors and Emerging - Market Banking Crises", NBER Working Paper Series, Working Paper 6370, January 1998.

HAURI, K. (2000), "Transnational Commercial Bribery and Corruption: a Challenge for the Financial Industry, Regulators and Supervisors", Eleventh International Conference of Banking Supervisors, Basel, 20-21 September.

FERGESON, C.K. (2004), "Ethical Banking”, ABA Banking Journal, 96(6): 14. Hellenic Bank Association (1997), Code of Banking Ethics, Athens.

HORTACSU, A. AND NUR GUNAY, E. (2004). Ethical Issues And Attitude in The Turkish Banking Sector. Eleventh World Congress for Social Economics. June 8-11, Albertville. France. Retrieved December 30, 2004 from the World Wide Web: http://www.socialeconomics.org/uploads/Hortacsu\%20OzkanGunay.pdf

HOENING, T. M. (1999), "Financial Regulation, Prudential Supervision, and Market Discipline: Striking a Balance", Conference on the Lessons from Recent Global Financial Crises, Federal Reserve Bank of Chicago, 1 October.

INTERNATIONAL MOSCOW BANK (2006), Code of Ethics, Retrieved August 25, 2006 from the World Wide Web: http://www.imb.ru/en/about/ethics_code/

LYNCH, J.J. (1991), Ethical Banking: Surviving in an Age of Default, Macmillan, Basingstoke.

MISHKIN, F. S. (2007), The Economics of Money, Banking, and Financial Markets, Eight Ed., Pearson/Addison Wesley Pub.

ÖÇAL, T. \& ÇOLAK, F. (1999), Financial System and Banks, Nobel Publishing, Ankara. 
PARASIZ, I. (2000), Modern Banking: Theory and Practice, Kuşak Ofset, İstanbul.

PROVIS, C. (2001), "Why is Trust Important", Reason in Practice, 1:2, 31-41.

ROSE, E.C (2004), Statistical Methods II: Multiple Regression SPSS, Supplementary Course Material, Toronto,

SCHWARTZ, M. S. (2002), "A Code of Ethics for Corporate Code of Ethics", Journal of Business Ethics, 41(1/2): 27-43.

SEKARAN, U. (2003), Research Methods For Business, Fourth Ed., John Wiley \& Sons, Inc..

SONGÜR, N.(2002), "The Competitive Powers Of SMEs in The Light Of The Basic Administration Problems In The Chamber Of Commerce in Northern Cyprus And Future Oriented Expectations", The SMEs in the 21st Century: Problems, Opportunities and Solution Proposal Symposium, 3-4 January 2002, Famagusta,

SOUTAR, G., MCNEIL AND C. MOLSTER (1994), "The Impact of the Work Environment on Ethical Decision Making: Some Australian Evidence," Journal of Business Ethics, 13, 327-339.

STEIN, O. AND YASSA, S. (2005), "The Code of banking practice: dealing with guarantors--requirements from 2004-05 (1) (ETHICS)", Journal of Banking and Financial Services, April Issue, Retrieved August 25, 2006 from the World Wide Web: http://www.highbeam.com/doc/1G1-132849866.html

ŞAFAKLI, O., (2003), "The Analysis of Banking and Financial Crises: Case of TRNC", Second Global Conference on Business \& Economics, July 5-7, Imperial College South Kensington Campus, London, England.

ŞAFAKLI, O.,(2005), "A Research on the Ethical Dimension of Banking Crises in the Turkish Republic of Northern Cyprus", Electronic Journal of Business Ethics and Organization Studies, 10 (2).

ŞAFAKLI, O. (2006), "Ethical Perceptions of Hotels towards the Loans of Development Bank and Commercial Banks in TRNC", Anatolia: An International Journal of Tourism and Hospitality Research, 17 (1).

TBB (2006), "Code of Banking Ethics", Approved with the Banking Regulation and Supervision Board's decision dated 15/06/2006, no. 1904, July 26, 2006, The Banks Association Of Turkey.

THE FIRST NATIONAL BANK IN TRINIDAD (2006), Code of Ethics, Retrieved August 25, 2006 from the World Wide Web: http://www.fnbtrinidad.com/CodeOfEthics.asp 
THE IMPACT OF ETHICAL PERCEPTIONS OF SMALL AND MEDIUM SIZED ENTERPRISES (SMES) ON THEIR BANK SATISFACTION AND SUBSEQUENT WORD OF MOUTH: CASE OF NORTHERN CYPRUS

THE BANK OF NEW YORK (2006), Code of Conduct, Retrieved August 25, 2006 from the World Wide Web: http://www.bankofny.com/htmlpages/acg_coc.htm

TSAHURIDU, E. AND PERRYER, C. (2002), "Ethics and Integrity: What Australian Organizations Seek and Offer in Recruitment Advertisements", Public Administration \& Management: An Interactive Journal, 7(4): 304-319.

WADDOCK, S. (2006), "Building the Institutional Infrastructure for Corporate Social Responsibility", Corporate Social Responsibility Initiative, Working Paper No. 32, Cambridge, MA: John F. Kennedy School of Government, Harvard University.

ZEITHAML, V.A., BERRY, L.L. AND PARASURAMAN, A. (1996), "The Behavioral Consequences of Service Quality”, Journal of Marketing, Vol. 52, July: 2-22. 